\title{
黃血鹽に對するフォルマリンの化學反應に就て（第一 報）
}

工學士桐 ケ滗孝

緒 言

黄血擥に對するフォルマリンの化學反應に關する研究は未だ交献の徵すべきもの無きが如し本問題に就き著 者の砸究は未だ完成せず從つて反應機構に關しては未だ㘓明せられざる處あるも反應生成物として一、二既知 の化合物を分離し得たれば妶には主として之に關する實驗操作及び結果を報告し併せて上記物質生成の原因を 考察し以て本題の反應機構を推論せんとす

\section{理 論 の 部}

黄血䑁を 2.5 倍の水に溶し之に同量の市販のフォルマリンを加へて $100^{\circ} \mathrm{C}$ の湯浴上にて 10 數時間加熱の際 密閉せずに撜挷反應せしめたるに淡綠色沈搌の器底に生ずるを認む此物體は元素分析並びに其性質を檢索した

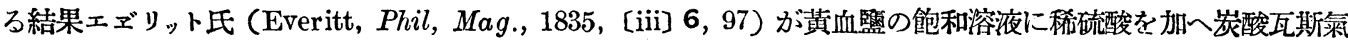
中にて蒸溜したる際青酸の發生と同時に得たる所謂青酸残渣 (Blausäurerückstand) 即ちカリウムフェロフェロ サイヤナイドの組成を有する物 $\left(\mathrm{K}_{2} \mathrm{Fe}_{2} \mathrm{Cy}_{6}\right)$ に甚だ類似するを認む

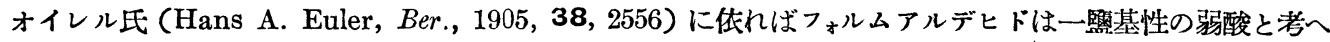

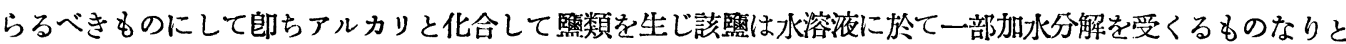
せり而して酸としてのフォルムアルデヒドの强さは解﨎恒數に依り約 $1.10-{ }^{14}\left(0^{\circ} \mathrm{C}\right)$ なりと計算せり

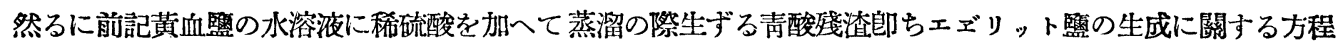
式は不明なるも今オイレル氏の證の如くフォルムアルデヒドは弱酸なりとの見解に基づき次の如き方程式が黄 血監に對し成立するものと思はる

$$
2 \mathrm{~K}_{4} \mathrm{FeCy}_{6}+6 \mathrm{H}_{2} \mathrm{C}(\mathrm{OH})_{2}=6 \mathrm{H}_{2} \mathrm{C} \cdot \mathrm{OK} \cdot \mathrm{OH}+\mathrm{K}_{2} \mathrm{Fe}_{2} \mathrm{Cy}_{6}+6 \mathrm{HCy} \cdots \cdots \cdots \cdots \cdots \cdots \cdots(1)
$$

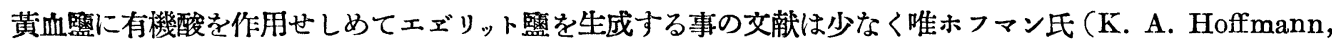
$L i e b, A n n ., 1906,352,66)$ に体つてのみ試みられたり氏は黄血監の水溶液に過剩の苳酸を加一加熱する際に 無機酸を加へたる時と同一の綠白色の結晶を得たり其分析の結果はエエ゙リット監と同一組成を有する事を確め たり

本實驗の反應中に青酸の發生の如何は反應の性質を闡明する上に重要なる意義を有するを以て後記（第二報 實驗 III）の如く蒸溜法に依り定量的に試驗せるも其發生の事實を認むる事を得ざりき唯反應中其溶液にシア ンイオンの生成する事實はピクリン酸を指示藥とする呈色反應により定性的に磪めたり尖その定性方法を詳記 せんに黄血監の規定液 5cc に市販のフォルマリン $5 \mathrm{cc}$ を混和しそれに少量のピクリン酸の溶液を添加して湯浴 上にて加熱するに反應溶液は漸次赤色に變じ來るを認む然るに上記黄血監及びフォルマリンの單獨溶液に於て 其の各々にピ クリン酸を加へ同樣加熱するに何れも赤色の呈色反應を認めず是に依つて觀るに黄血監溶液及び フォルマリンの反應の結果生成したるシアンイオンがピクリン酸と作用してイソパープル酸の加里監の生成に 依る赤色の呈色反應の結果と認む（照 Rosenthaler, Der Nachweis organischer Verbindungen, 492) 蓋 し反應夜中に常に過剩にフォルマリンの存在せるの故を以て發生する青酸は直ちにフォルマリンに作用せらる〉 
が焉に蒸溜の際溜出し來らざるものとも察せらる

上記淡綠色沈澱を滤渦したる滤液よりグリコールアミドを分離し得なるがこのものの生成に關する反應機構 は末だ明榷なるを得ざるも反應中にシアンイオンの存在を認め得るを以て若し菏酸が發生するとすれいば第二段 の反應として

$$
\mathrm{CH}_{2} \mathrm{O}+\mathrm{HCy}=\mathrm{CH}_{2} \mathrm{OHCy}
$$

即ちニトリルを中間に生じ此のものが更に少量の水と $100^{\circ} \mathrm{C} に$ 加熱する際に锒化せられてグリコールアミドを 生成するとの交献 (Theodor St. Warnunis u. Franz Sacks, Ber., 1904, 37, 2636)に基き次の式の如く反應 の經過することも想像し得らる

$$
\mathrm{CH}_{2} \mathrm{OHC}+\mathrm{H}_{2} \mathrm{O}=\mathrm{CH}_{2} \mathrm{OH} \cdot \mathrm{CONH}_{2}
$$

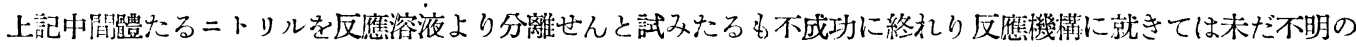
點多く又㸴究上にも䐨さざるところ多し更に稿を改めて報告すべし

\section{實 騟 の 部}

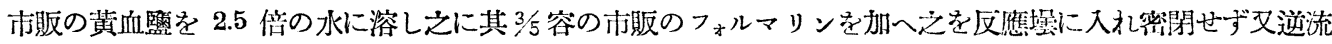
冷却器を附せずして攪拌しつ〉湯浴 $\left(100^{\circ} \mathrm{C}\right)$ 內にて 10 數時問加熱するに器底に淡綠色の沱澱を生ず此沈澱を 濾過したる濾液にアルコール（98\%）を加へて殘留する未反應の黄血監を㴷澱せしめたる滤液に同量のエーテ ルを加へて分液漏斗中にて烈しく振蕰したる後靜置するに 2 層に分離す上層の液を分離してアルコールエーテ

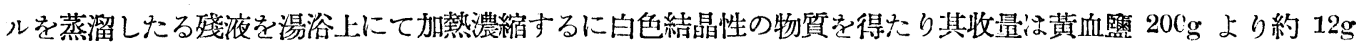
を得たり此の物を更に $98 \%$ のアルコール溶液より再結晶せしめ濃硫酸复空乾燥器中にて乾燥せり其融勄は 118 $\sim 119^{\circ} \mathrm{C}$ なり

元素分析の結果は次表の如し

分 析

1. 供試料 $0.1835 \mathrm{~g}: \mathrm{CO}_{2} \quad 0.2139 \mathrm{~g} \quad \mathrm{H}_{2} \mathrm{O} \quad 0.103 \mathrm{~g}$

2. 供試料 ( $11016 \mathrm{~g}$ : $\quad \mathrm{N} 16.6 \mathrm{cc}\left(15^{\circ} \mathrm{C} 756 \mathrm{~mm}\right)$ $\begin{array}{llllll}\mathrm{C}_{2} \mathrm{H}_{5} \mathrm{NO}_{2} & \text { に對す 万計算值 C } 32.00 \% & \mathrm{H} & 6.67 \% & \mathrm{~N} & 18.67 \%\end{array}$

實瞼值 " $31.77 " 6.70 \% " 18.82$

上記結果に依れば試料物質はグリコール酸アミドなるべしと思はるっも佾之を合成によりて得なる物と比較 せんが焉にカールバウム製グリコール酸を使用しハインツ氏の方法 (Heinz, J. Ber., 1861, 446; Lieb. Ann., 1862，123，316）に依り先づグリコール酸エステルを作り之に濃アンモニアを作用せしめ得なる合成グッコー ルアミドと混融試驗を行ふに同一物なる事を確めたり叙上の實驗結果よりして本物質はグリコール酸アミドな

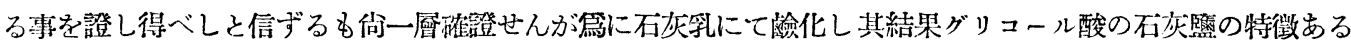

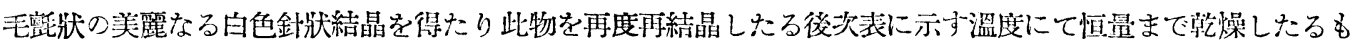
のを分析せしに其結果次の如し

分 析

1. 供試料 $0.284 \mathrm{gg}: \quad \mathrm{CO}_{2} \quad 0.2145 \mathrm{~g} \quad \mathrm{H}_{2} \mathrm{O} \quad 0.0796 \mathrm{~g}$ 供試料は $100^{\circ} \mathrm{C}$ に憼燥す

2. 供試料 $0.3817 \mathrm{~g}$ : $\mathrm{CaO} 0.1132 \mathrm{~g}$ 供試料杜 $120 \sim 130^{\circ} \mathrm{C}$ 火乾燥す

$\left(\mathrm{C}_{2} \mathrm{H}_{3} \mathrm{O}_{3}\right)_{2} \mathrm{Ca}$ K對す万計算值 $\quad \mathrm{C} 25.26 \% \mathrm{H} \mathrm{3.16 \%} \quad \mathrm{CaO} 29.46 \%$

實驗值 " 25.54 " 3.44 " 29.66

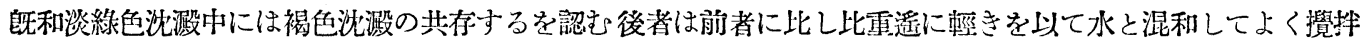




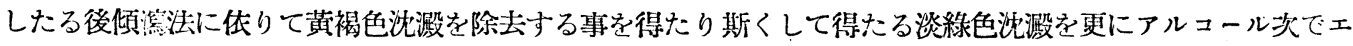

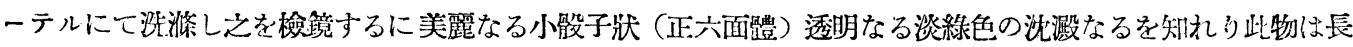
く空氣中に放置するも頗る安定なり上記淡綠色の沈澱は定性試驗の結果加里を含有すること並びにアルカリに 体りて水酸化第一鐵と黄血監とに分解する事によりフェロシアン基以外の鐵を含む化合物なることを知れり依 て下記方法によりて分析を試みたり鐵の總含有量は濃硫酸にて加熱分解し常法により酸化第二鐵として定量せ り加里量は Sodium cobaltnitrite を用ひて計算する加里定量法に体れり (E. Cleyfert, Ch. Abst., 1923, 17, 2544）シアン化物の量は間接に見出し得べきも其の正確量は必要なる意義を有ずべきを以て I. Belluccd and B. Ricca. (Ch. Alst., 1924, 18, 3334) の方法によりてシアン化物を定量せり炭素水素及び窒素は元素分析に

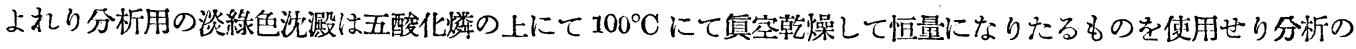
結果は次の如し

分 析

1. 供 試 料 $0.3896 \mathrm{~g} \quad \mathrm{Fe}_{2} \mathrm{O}_{3} \quad 0.1797 \mathrm{~g}$ 供試料 $0.1261 \mathrm{~g} \quad \mathrm{Fe}_{2} \mathrm{O}_{3} \quad 0.0407 \mathrm{~g}$

2. 供試料 $0.1759 \mathrm{~g}$ 供試料 $0.1238 \mathrm{~g}$

3. 供試料 $0.1385 \mathrm{~g}$ 供試料 $0.1950 \mathrm{~g}$

4. 供陚料 $0.5849 \mathrm{~g}$

5. 供試料 $0.5362 \mathrm{~g}$ $\begin{array}{llll}\mathrm{CO}_{2} & 0.1271 \mathrm{~g} & \mathrm{H}_{2} \mathrm{O} & 0.0012 \mathrm{~g}\end{array}$

$\begin{array}{lllll}\mathrm{CO}_{2} & 0.0889 \mathrm{~g} & \mathrm{H}_{2} \mathrm{O} & 0.0038 \mathrm{~g}\end{array}$

$\mathrm{N} \quad 28.7 \mathrm{cc}\left(12.6^{\circ} \mathrm{C} 754 \mathrm{~mm}\right)$

$\mathrm{N} \quad 41.2 \mathrm{cc}\left(17.2^{\circ} \mathrm{C} 757 \mathrm{~mm}\right)$

$\mathrm{K}_{2} \mathrm{NaCo}\left(\mathrm{NO}_{2}\right)_{6} \cdot \mathrm{H}_{2} \mathrm{O} \quad 0.7190 \mathrm{~g}$

Cy $\quad 0.2377 \mathrm{~g}$

$\mathrm{Fe} \quad \mathrm{C}$

計算值 $\left(\mathrm{K}_{2} \mathrm{Fe}_{2} \mathrm{Cy}_{6}\right)$

實 驗 做

$32.26 \%$

32.21

32.28

\begin{tabular}{l}
\multicolumn{1}{c}{ C } \\
$20.81 \%$ \\
19.7
\end{tabular}

19.54

$\mathrm{H}$
$0 \%$
0.68

0.32

$\mathrm{N}$
$\mathbf{2 4 . 2 9 \%}$
24.20

24.26

如上の結果よりしてこの淡綠色の沈澱は $\mathrm{K}_{2} \mathrm{Fe}_{2} \mathrm{Cy}_{6}$ の組成と相符合す

エエ゙レット氏 (Everitt, Phil. Mag., 1835, [iii] 6, 97)は黄血盒の饱和溶液に稀硫酸を加へ炭酸瓦斯氣中にて 蒸溜したる際青酸の弡生と同時に他方に所謂青酸殘渣と稱寸る處のもの郎ちカリウムフェロフェロサイヤナイド の組成を存するものが生成せりと報告せり著者の得たる此淡綠色の沈澱は前記青酸殘渣と甚げ類似するを認む 此青酸殘渣に就きホフマン氏等 (K. A. Hoffmann, O. Heine, u. F. Höchtlen, Lieb. Ann., 1904, 337, 1) は詳細なる㸴究を試みたり依つて上記諸氏の試驗せし結果と著者が淡綠色の沈澱につき試みたる結果と此較す る焉にホフマン氏等の試みたる次の事項に基づき著者の得たる淡綠色の沈澱に就き試驗せり

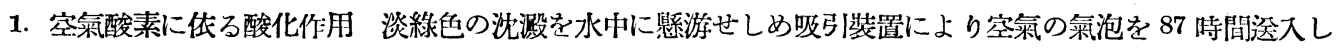
て酸化試驗を試みたり

2. アルカリ類に依る分解作用 炭酸アムモニウム又はアムモニア又は葓性曹達 (10\%) を少量の水中に䀣游: せしめたる淡緑色の㴤澱に作用せしめ分解作用の有無を檢せり

3. 硝酸の酸化作用 稀硫酸 $(1: 2)$ を溫め之を淡繀色の沈澱に作用せしめたる際に次の項に記載するが如く

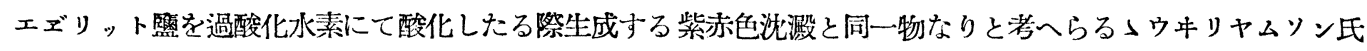
ヴィオレット $\left(\mathrm{K} \cdot \mathrm{Fe} \cdot \mathrm{FeCH}_{6} \cdot \mathrm{H}_{2} \mathrm{O}\right)$ に變化するや否やを試みたり

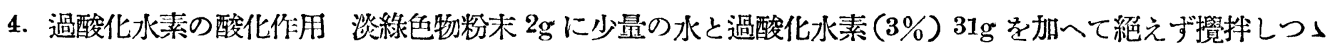
分液漏斗より徐々に硫酸 (1\%) $27 \mathrm{~g}$ を滴下し 24 時間常溫にて鹠找せしめたる後其酸化生成物を光線の投射に より紫赫を旺するや否やを試みたり 
上記諸項の試驗結果をホフマン氏等の結果と比較照對して次表に示さむ

\begin{tabular}{|c|c|c|c|c|c|}
\hline & $\mathrm{O}_{2}$ in Air & $\begin{array}{l}\mathrm{NH}_{4} \mathrm{CO}_{3} \text { 或 } \\
\text { は } \mathrm{NH}_{4} \mathrm{OH}\end{array}$ & $\mathrm{NaOH}$ & $\mathrm{H}_{\mathrm{NO}}{ }_{3}$ & $\mathrm{H}_{2} \mathrm{O}_{2}$ \\
\hline $\begin{array}{l}\text { フマン氏等の } \\
\text { ボ沈澱 }\end{array}$ & 不完 全 & 徐々に分解す & 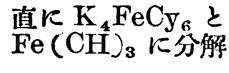 & $\begin{array}{l}\text { Williamson's } \\
\text { Violet 生成す }\end{array}$ & 景赤色 \\
\hline 綠 色 沈 澱 & 同 & 分解せず & 同 & 生成せず & \\
\hline
\end{tabular}

過酸化水素に体る酸化生成物は上記の如く光線の投射により紫赤色を呈す此酸化生成物を滤過し更に水を以て 硫酸基の反應なきに至るまで允分に洗涤したる後五酸化燐の真空乾燥器中にて恒量となるまで乾燥し此物が果 して所謂ウキリアムソン氏ヴィオレットと稱せらるつ物と同一物なるや否やを比較試驗せり

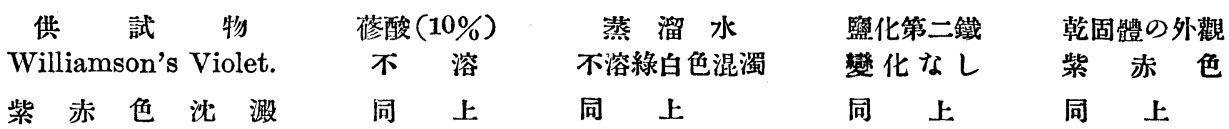

上記過酸化水素による酸化生成物の元素分析結果は次の如し分析方法は淡綠色の沈澱の場合と略同樣の方法 によれり

分 析

1. 供試料 $0.1838 \mathrm{~g}$

$$
\begin{array}{llllll}
\text { 1. 供試料 } & 0.1838 \mathrm{~g} & \mathrm{Fe}_{2} \mathrm{O}_{3} & 0.0897 \mathrm{~g} & & \\
\text { 2. 供試料 } & 0.2553 \mathrm{~g} & \mathrm{CO}_{2} & 0.2010 \mathrm{~g} & \mathrm{H}_{2} \mathrm{O} & 0.0096 \mathrm{~g}
\end{array}
$$

3. 供試料 $0.1481 \mathrm{~g} \cdot \mathrm{N} \quad 32.9 \mathrm{cc}\left(5.2^{\circ} \mathrm{C} 746 \mathrm{~mm}\right)$

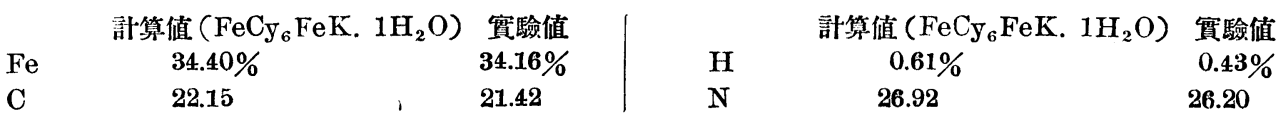

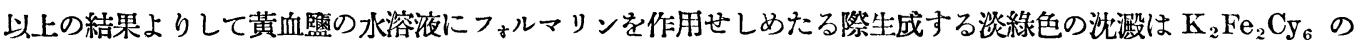

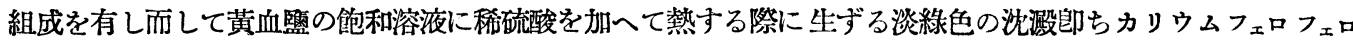
サイアナイドの化合物と甚だ類似の物なる事を知るを得べし

要 旨

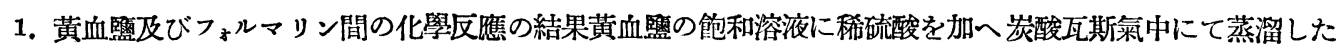
る祭青酸の發生と同時に得たる所謂靑酸殘渣郎ち $\mathrm{K}_{2} \mathrm{Fe}_{2} \mathrm{Cy}_{6}$ の組成を有するものと甚げ類似の淡線色結晶性 の物質を分離し得たり

2. 上記淡綠色の沈澱を滤過したる濾夜よりグリコールアミドを分離し得たり

附記 本問題を與へられ且つ研究中は終始御懇篤なる 御指導を睗はりナる井上:仁吉博士に對し玄に謹人て感謝の 意无表す

（東北帝國大學工學部化學工學科数室）（昭和四年八月三○日受理）

\section{黃血鹽に對するフォルマリンの化學反應に就て（第ニ 報）}

工學士桐 ケ等孝

緒

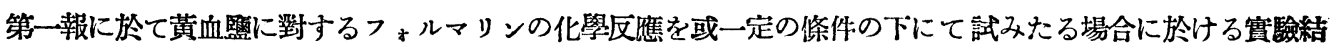
果に就き報告したるが本報は前報に引續き其反應條件を幾分變じたる場合に於て反應生成物並びに其性質の上 